\title{
Playfulness, perceived stress and coping with stress approaches in teacher candidates in various departments
}

\author{
Burcu Güvendi ${ }^{1}$ \\ Muhsin Hazar ${ }^{2}$
}

\begin{abstract}
The purpose of this research is to examine the playfulness, perceived stress and overcoming the stress styles in teacher candidates, identify the relationships between. The research group of 338 $(\bar{X}$ yaş $=20.31 \pm 1.25)$ physical education, pre-school and classroom teachers, of which 242 were females $(\bar{X}$ yaş $=20.27 \pm 1.25)$ and 96 were males $(\bar{X}$ yaş $=20.44 \pm 1.25)$. As data collection tool, 'Playfulness Scale', 'Perceived Stress Scale' and 'Coping with Stress Scale' were used. In the analysis of data, Spearman Product Moment Correlation Analysis, Kruskal Wallis and Mann-Whitney U Tests from non-parametrical tests were used due to normal distribution conditions are not fulfilled. In regard to departments, significant difference was identified in teacher candidate's dimensions of playfulness scale and coping with stress scale $(\mathrm{p}<0.05)$. The results of physical education teacher candidates being more playful compared to teacher candidates in other departments, and pre-school and class teacher candidates using the consulting to social support approach more were reached.
\end{abstract}

Keywords: Playfulness; Perceived Stress; Coping with Stress.

\section{Introduction}

Stress is defined as the reaction occurring in the event of a physical or psychological strain formed on the person by an action or situation (Hellriegel et al, 1992). Also, stress is a mental state occurring as a result of a reaction against an action, situation or a psychological strain on the person, and a state that is negative for an organism, able to deform its health (Aytac, 2009).

Facing such situations, students use some functional and non-functional strategies. This also reveals how they cope with stress. Coping is directed to perceived threat and mitigating the resulting damage (Lazarus, 1966). In other words, coping is to improve one's resources, self-control and self-confidence to manage and mitigate the perceived stress intensity (Lazarus, 1999).

When we look at the definitions about game, some believed that it can be defined as its origin and foundation is a way of getting rid of excessive life energy. In other words, game is to ensure that people do not indulge their personality. Other assumptions state that the origin of game is a tendency to be able to do something or to be able to determine something within the desire to dominate and need to compete (Tukenmez, 2009).

Games offer enthusiasm, excitement, full involvement and entertainment for children in a learning environment. Use of games in a classroom greatly motivates children, children involves in activity entirely and attitudes of children towards classes develop over time. Although children compete with each other, they cooperate when playing games. Playing games require active participation. Therefore, games will maintain learning of children further and undoubtedly increase their motivation and encourage their active participation (Tertemiz, 2000).

\footnotetext{
${ }^{1}$ Research Assistant, İstanbul University, Sports Science Faculty, burcuguvendi@gmail.com

2 Assoc.. Prof., Gazi University, Sports Science Faculty, muhsin@gazi.edu.tr
} 
Güvendi, B., \& Hazar, M. (2016). Playfulness, perceived stress and coping with stress approaches in teacher candidates in various departments. Journal of Human Sciences, 13(3), 5796-5806. doi:10.14687/jhs.v13i3.4348

In our study, the concept of 'playfulness' found under the name of characteristic of game, which is a shared course in the physical education teaching, pre-school teaching and classroom teaching departments, stand out. Although playfulness is a subject as old as game itself, scientific works in this matter are relatively new. Many scientists accept playfulness, which is making a situation or environment more fun or enjoyable, is a personal disposition (Main point similar to happiness) (Barnett 1990; Glynn and Webster 1992; Schaefer 1993; Trevlas et al. 2003). Playing games is known to have an important role in development of people (Schaefer, 1993; Singer \& Singer, 1990; Vygotsky, 1978) and recent research show that some people are more disposed to playfulness than others by birth (Barnett, 2007, 2011-12; Bozionelos \& Bozionelos, 1999; Glynn \& Webster, 1992). Although game appears as a behavior, playfulness is defined as the disposition to create enjoyable, humorous or joyous situations for oneself or probably for others (Barnett, 2007). Playful individuals can have a different perspective in first stress evaluation. This, in turn, may cause a situation which an individual may consider as normally stressful to perceive as a less stressful situation to force the resources. As an opposite, the reason for less playful individuals to perceive the situation as stressful may be insufficiency of resources. As a result, while the reasons of stress causes smaller bumps in the lives of playful individuals, less playful individuals may see these as very important situations (Magnuson and Barnett, 2013).

Teachers with the ability of playability can make teaching and education environment more creative together with their students. This will enable active participation of children in classes and motivate them further. Besides, this could make it easier for them to deal with the problems they face during education.

\subsection{Focus of the Study}

Especially as it is considered that university students studying in three different departments will work with small children when they graduate, how they will deal with stressful situations become more important. Also, teaching the course of game in the curriculums of physical education, classroom teaching and pre-school teaching departments and these students will be teaching most information to their students when they become teachers through gaming has revealed the question of what their playfulness levels are. In this context, the purpose of this research is to examine the playfulness, perceived stress and coping with stress styles in teacher candidates according to some independent variables and identify the relationships between.

\section{Methodology}

\subsection{Participants}

In this research, where the playfulness, perceived stress and coping with stress styles in teacher candidates studying in various departments are examined according to some independent variables and the relationships between are identified, general survey model was used. The study group of the research consists of 338 teacher candidates, 242 females and 96 males, in the province of İstanbul, studying in Physical Education Teaching (Female $=49, \bar{X}$ yaş=20.34 \pm 1.54 , Male $=66$,

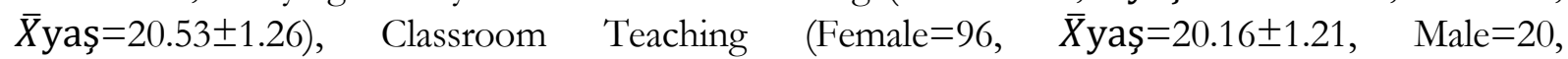

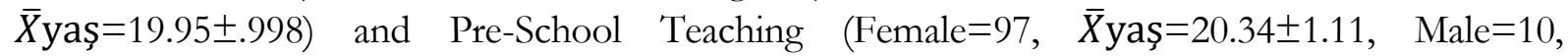
$\bar{X}$ yaş $=20.80 \pm 1.39$ ), which most of them exercise and are in 1st, 2. 3rd and 4th class, with general age averages of $(\bar{X}$ yaş $=20.31 \pm 1.25)$.

\subsection{Procedures}

Scales were applied at the beginning or end of the courses of students, after necessary permits were obtained. As data collection tool, 'Playfulness Scale', 'Perceived Stress Scale' and 'Coping with Stress Scale' were used in the research. 
Güvendi, B., \& Hazar, M. (2016). Playfulness, perceived stress and coping with stress approaches in teacher candidates in various departments. Journal of Human Sciences, 13(3), 5796-5806. doi:10.14687/jhs.v13i3.4348

\subsection{Instruments}

2.3.1.Playfulness scale: Ages 18-22 playfulness scale was developed by Hazar (2015). From the scale which was confirmatory factor analyzed, 8 items were removed and the remaining 25 items $(r=31$ and $r=57)$ showed a 5 factor structure. For the reliability of playfulness scale, Cronbach Alpha value was calculated as 0,86 . Sub factors were named as 1 . Passion for games, 2. Risk taking, 3. Social adaptation, 4. Desire to play and 5. Enjoyment.

2.3.2. Perceived stress scale: Perceived Stress Scale (PSS) was developed by Cohen, Kamarck and Mermelstein (1983). Adaptation to Turkish was made by Eskin et al. (2013). Consisting of a total of 14 items, PSS is designed to measure how stressful certain situations in a person's life are perceived. Participants evaluate each item on the 5 point Likert scale, varying between "Never (0)" and "very often (4)". PSS-14 items were gathered under two factors referred as inadequate self-efficacy perception and stress/discomfort perception. 7 of the items containing positive statement are scored in reverse. Reverse scored items are: 4, 5, 6, 7, 9, 10, 13. While the scores of PSS-14 vary between 0 and 56, high score points to the excessive stress perception of the individual.

2.3.3. Coping with stress scale: Developed by Folkman and Lazarus (1980) for the purpose of being able to identify the ways people use to cope with general or distinctive stress situations, and adaptation to Turkish, validity and reliability works were made by Sahin and Durak (1995). As a result of factor analyses, it was seen that this scale was divided into two as active/passive styles oriented to problem and active/passive styles oriented to emotions; and may be divided into 5 subscales referred as self-confident, optimistic, unconfident and submitting-desperate approaches and "consulting social support" (Sahin and Durak, 1995). When the sub-scales are looked at;

2.3.3.1. Self-Confident Approach; measures that, against stressful event or situations, the individual has self-confidence to cope effectively with this situation or event and his attitude for coping with the problem in a planned way $(8,10,14,16,20,23,26)$.

2.3.3.2. Unconfident Approach; defines that the individual is awaiting a miracle to cope with stressful event or situation, believe that he can't cope with it and in emotions of desperation $(3,7,11,19,22,25,27,28)$.

2.3.3.3. Optimistic Approach; consists of items containing finding positivity from stressful events or situations, believing in coping, that is to say, being optimistic $(2,4,6,12,18)$.

2.3.3.4.Submitting Approach (Desperate Approach); includes the attitudes of individual completely accepting the stressor encountered, retreating with the belief of not being able to cope and giving up on fighting $(5,13,15,17,21,24)$.

2.3.3.5. Consulting Social Support; consists of items including coping with stress ways such as getting help from others, looking for support to cope with an event or situation causing stress $(1,9,29,30)$.

\subsection{Analysis of Data}

Statistical analyses performed within scope of the research was made by SPSS 20 statistics software suite. As statistical method in evaluation of data; descriptive statistics (frequency, arithmetic average, standard deviation), Spearman Product-Moment Correlation Analysis, Kruskal Wallis and Mann-Whitney $U$ tests of non-parametrical tests because normal distribution conditions are not fulfilled.

\section{Findings}

According to the findings of the study to examine the playfulness, perceived stress and coping with stress styles in teacher candidates according to some independent variables and identify the relationships between; 
Güvendi, B., \& Hazar, M. (2016). Playfulness, perceived stress and coping with stress approaches in teacher candidates in various departments. Journal of Human Sciences, 13(3), 5796-5806. doi:10.14687/ihs.v13i3.4348

Table 1. Average Scores of Participants on Scales

\begin{tabular}{|c|c|c|c|c|c|c|c|c|c|c|c|c|c|c|c|}
\hline \multirow{2}{*}{ Scales } & \multicolumn{5}{|c|}{ Physical Education Teaching } & \multicolumn{5}{|c|}{ Classroom Teaching } & \multicolumn{5}{|c|}{ Pre-School Teaching } \\
\hline & $\mathrm{n}$ & Min. & Max. & Avg. & ss & $\mathrm{n}$ & Min. & Max. & Avg. & ss & $\mathrm{n}$ & Min. & Max. & Avg. & ss \\
\hline Playfulness & 115 & 44 & 125 & 87.2 & 16,3 & 116 & 35 & 122 & 79.1 & 17.5 & 107 & 44 & 111 & 77.8 & 13.8 \\
\hline $\begin{array}{l}\text { Perceived } \\
\text { Stress }\end{array}$ & 115 & 17 & 54 & 27.7 & 5,91 & 116 & 12 & 49 & 28.1 & 6.58 & 107 & 10 & 52 & 28.1 & 6.42 \\
\hline $\begin{array}{l}\text { Coping with } \\
\text { Stress }\end{array}$ & 115 & 25 & 85 & 47.7 & 9.76 & 116 & 25 & 68 & 47.3 & 7.70 & 107 & 26 & 68 & 45.3 & 7.47 \\
\hline
\end{tabular}

Table 2. Result of Playfulness Scale on Departments Kruskal Wallis Test

\begin{tabular}{|c|c|c|c|c|c|c|c|c|c|c|c|c|c|c|c|}
\hline \multirow{2}{*}{$\begin{array}{l}\text { Playfulness } \\
\text { scale }\end{array}$} & \multicolumn{5}{|c|}{ Physical Education Teaching } & \multicolumn{5}{|c|}{ Classroom Teaching } & \multicolumn{5}{|c|}{ Pre-School Teaching } \\
\hline & $\mathrm{n}$ & $\begin{array}{l}\text { Order } \\
\text { avg. }\end{array}$ & Sd. & $X^{2}$ & $\mathrm{p}$ & $\mathbf{n}$ & $\begin{array}{l}\text { Order } \\
\text { avg. }\end{array}$ & Sd. & $X^{2}$ & $\mathrm{p}$ & $\mathrm{n}$ & $\begin{array}{l}\text { Order } \\
\text { avg. }\end{array}$ & Sd. & $X^{2}$ & $\mathrm{p}$ \\
\hline $\begin{array}{l}\text { Passion for } \\
\text { Games }\end{array}$ & 115 & 204.52 & 2 & 22.56 & 0.00 & 116 & 153.36 & 2 & 22.56 & 0.00 & 107 & 149.36 & 2 & 22.56 & 0.00 \\
\hline Risk taking & 115 & 211.03 & 2 & 31.75 & 0.00 & 116 & 146.12 & 2 & 31.75 & 0.00 & 107 & 150.22 & 2 & 31.75 & 0.00 \\
\hline Desire to play & 115 & 201.27 & 2 & 18.87 & 0.00 & 116 & 156.37 & 2 & 18.87 & 0.00 & 107 & 149.59 & 2 & 18.87 & 0.00 \\
\hline Enjoyment & 115 & 194.61 & 2 & 13.52 & 0.001 & 116 & 165.18 & 2 & 13.52 & 0.001 & 107 & 147.20 & 2 & 13.52 & 0.001 \\
\hline
\end{tabular}

According to Table 2; significant difference is seen in the sub-dimensions of Passion to Play, Risk Taking, Desire to Play and Enjoyment of playfulness on departments scale $(\mathrm{p}<0.05)$, no significant difference was seen in the social adaptation sub-dimension ( $\mathrm{p}>0.05)$. The results of Mann-Whitney $\mathrm{U}$ test, which was performed to determine between which departments the difference is, are given below;

Table 3. Result of Playfulness Scale on Departments U-Test

\begin{tabular}{ccccccc}
\hline $\begin{array}{c}\text { Playfulness } \\
\text { Scale }\end{array}$ & Department & $\mathbf{n}$ & Order avg. & Order tot. & $\mathbf{U}$ & $\mathbf{p}$ \\
\hline Passion for & PET & 115 & 133.07 & 15302.50 & \multirow{2}{*}{4707.50} & 0.00 \\
Games & CRT & 116 & 99.08 & 11493.50 & & \\
Risk Taking & PET & 115 & 137.28 & 15787.50 & 4222.50 & 0.00 \\
& CRT & 116 & 94.90 & 11008.50 & & \\
Desire to & PET & 115 & 131.42 & 15113.00 & 4897.00 & 0.00 \\
Play & CRT & 116 & 100.72 & 11683.00 & & \\
Enjoyment & PET & 115 & 125.97 & 14487.00 & 5523.00 & 0.02 \\
Passion for & CRT & 116 & 106.11 & 12309.00 & & 0.00 \\
Games & PET & 115 & 129.46 & 14887.50 & 4087.50 & \\
Risk Taking & PST & 107 & 92.20 & 9865.50 & & 0.00 \\
Desire to & PET & 115 & 131.74 & 15150.50 & 3824.50 & \\
Play & PST & 107 & 89.74 & 9602.50 & & 0.00 \\
Enjoyment & PET & 115 & 127.85 & 14703.00 & 4272.00 & \multirow{2}{*}{0.00} \\
\hline
\end{tabular}


Güvendi, B., \& Hazar, M. (2016). Playfulness, perceived stress and coping with stress approaches in teacher candidates in various departments. Journal of Human Sciences, 13(3), 5796-5806. doi:10.14687/ihs.v13i3.4348

Table 4. Result of Coping with Stress Scale on Departments Kruskal Wallis Test

\begin{tabular}{|c|c|c|c|c|c|c|c|c|c|c|c|c|c|c|c|}
\hline \multirow{2}{*}{$\begin{array}{l}\text { Coping with } \\
\text { Stress } \\
\text { Scale }\end{array}$} & \multicolumn{5}{|c|}{ Physical Education Teaching } & \multicolumn{5}{|c|}{ Classroom Teaching } & \multicolumn{5}{|c|}{ Pre-School Teaching } \\
\hline & n & $\begin{array}{c}\text { Order } \\
\text { avg. }\end{array}$ & Sd. & $X^{2}$ & $\mathbf{P}$ & $\mathrm{n}$ & $\begin{array}{c}\text { Order } \\
\text { avg. }\end{array}$ & Sd. & $X^{2}$ & $\mathrm{p}$ & $\mathrm{n}$ & $\begin{array}{c}\text { Order } \\
\text { avg. }\end{array}$ & Sd. & $X^{2}$ & $\mathrm{p}$ \\
\hline $\begin{array}{l}\text { Optimistic } \\
\text { Approach }\end{array}$ & 115 & 146.81 & 2 & 6.34 & 0.04 & 116 & 176.58 & 2 & 6.34 & 0.04 & 107 & 186.21 & 2 & 6.34 & 0.04 \\
\hline $\begin{array}{l}\text { Consulting } \\
\text { social support }\end{array}$ & 115 & 183.68 & 2 & 10.15 & 0.01 & 116 & 172.28 & 2 & 10.15 & 0.01 & 107 & 151.25 & 2 & 10.15 & 0.01 \\
\hline
\end{tabular}

According to Table 4; significant difference is seen in the sub-dimensions of Optimistic Approach and Consulting Social Support Approach from coping with stress scale $(\mathrm{p}<0.05)$, no significant difference was seen in other sub-dimensions ( $\mathrm{p}>0.05)$. The results of Mann-Whitney U test, which was performed to determine between which departments the difference is, are given below;

Table 5. Result of Coping with Stress Scale on Departments U-Test

\begin{tabular}{ccccccc}
\hline $\begin{array}{c}\text { Coping with } \\
\text { Stress Scale }\end{array}$ & Department & $\mathbf{n}$ & Order Avg. & $\begin{array}{c}\text { Order } \\
\text { difference }\end{array}$ & U & p \\
\hline Optimistic & PET & 115 & 121.71 & 13997.00 & 4978.00 & 0.01 \\
Approach & PST & 107 & 100.52 & 10756.00 & & 0.02 \\
Consulting & PET & 115 & 106.13 & 12204.50 & 5534.50 & 0.02 \\
Social Support & CRT & 116 & 125.79 & 14591.50 & & \\
\hline
\end{tabular}

Table 6. Result of Scale Sub-Dimensions on Departments by Gender U-Test

\begin{tabular}{|c|c|c|c|c|c|c|c|}
\hline $\begin{array}{c}\text { Physical Education } \\
\text { Teaching }\end{array}$ & Scale Sub-Dimensions & Gender & $\mathbf{n}$ & Order avg. & Order tot. & $\mathbf{U}$ & $\mathrm{p}$ \\
\hline \multirow{4}{*}{ Playfulness Scale } & \multirow{2}{*}{ Passion for Games } & Female & 49 & 50.11 & 2455.50 & \multirow{2}{*}{1230.50} & \multirow[t]{2}{*}{0.03} \\
\hline & & Male & 66 & 63.86 & 4214.50 & & \\
\hline & \multirow{2}{*}{ Enjoyment } & Female & 49 & 45.78 & 2243.00 & \multirow{2}{*}{1018.00} & \multirow{2}{*}{0.00} \\
\hline & & Male & 66 & 67.08 & 4427.00 & & \\
\hline \multirow{2}{*}{ Perceived Stress Scale } & \multirow{2}{*}{ Stress Perception } & Female & 49 & 71.94 & 3525.00 & \multirow{2}{*}{934.00} & \multirow{2}{*}{0.00} \\
\hline & & Male & 66 & 47.65 & 3145.00 & & \\
\hline \multirow{2}{*}{ Coping with Stress Scale } & \multirow{2}{*}{ Submitting Approach } & Female & 49 & 50.29 & 2464.00 & \multirow{2}{*}{1239.00} & \multirow{2}{*}{0.03} \\
\hline & & Male & 66 & 63.73 & 4206.00 & & \\
\hline Classroom Teaching & Scale Sub-Dimensions & Gender & $\mathrm{n}$ & Order avg. & Order tot. & $\mathbf{U}$ & $\mathrm{p}$ \\
\hline \multirow{6}{*}{ Playfulness scale } & \multirow{2}{*}{ Social Adaptation } & Female & 96 & 62.33 & 5983.50 & \multirow{2}{*}{592.50} & \multirow{2}{*}{0.01} \\
\hline & & Male & 20 & 40.13 & 802.50 & & \\
\hline & & Female & 96 & 61.46 & 5900.50 & & \\
\hline & Desire to Play & Male & 20 & 44.28 & 885.50 & 675.50 & 0.04 \\
\hline & Enioyment & Female & 96 & 61.32 & 5886.50 & 689.50 & 0.05 \\
\hline & Enjoyment & Male & 20 & 44.98 & 899.50 & 089.50 & 0.05 \\
\hline \multirow{2}{*}{ Perceived Stress Scale } & \multirow{2}{*}{ Insufficient Self-Efficacy } & Female & 96 & 53.60 & 5145.50 & \multirow{2}{*}{489.50} & \multirow{2}{*}{0.00} \\
\hline & & Male & 20 & 82.03 & 1640.50 & & \\
\hline Pre-School Teaching & Scale Sub-Dimensions & Gender & $\mathrm{n}$ & Order avg. & Order tot. & $\mathbf{U}$ & $\mathrm{p}$ \\
\hline \multirow{4}{*}{ Playfulness Scale } & \multirow{2}{*}{ Passion for Games } & Female & 97 & 51.29 & 4975.50 & \multirow{2}{*}{222.50} & \multirow{2}{*}{0.01} \\
\hline & & Male & 10 & 80.25 & 802.50 & & \\
\hline & & Female & 97 & 52.08 & 5052.00 & & \\
\hline & Enjoyment & Male & 10 & 72.60 & 726.00 & 299.00 & 0.04 \\
\hline \multirow{2}{*}{ Coping with Stress Scale } & \multirow{2}{*}{ Optimistic Approach } & Female & 97 & 51.30 & 4976.00 & \multirow{2}{*}{223.00} & \multirow{2}{*}{0.01} \\
\hline & & Male & 10 & 80.20 & 802.00 & & \\
\hline
\end{tabular}


Güvendi, B., \& Hazar, M. (2016). Playfulness, perceived stress and coping with stress approaches in teacher candidates in various departments. Journal of Human Sciences, 13(3), 5796-5806. doi:10.14687/jhs.v13i3.4348

According to Table 6; significant difference was identified in playfulness scale on gender for physical education teaching (Passion for Games $\mathrm{U}=1230.500, \mathrm{p}<0.05$ and Enjoyment $\mathrm{U}=1018.000, \mathrm{p}<0.05$ ), classroom teaching (Desire to Play $\mathrm{U}=675.500, \mathrm{p}<0.05$, Social Adaptation $\mathrm{U}=592.500, \mathrm{p}<0.05$ and Enjoymen $\mathrm{U}=689.500, \mathrm{P}<0.05$ ) and lastly pre-school teaching (Passion for Games $\mathrm{U}=222.500, \mathrm{p}<0.05$ and Enjoyment $\mathrm{U}=299.000, \mathrm{p}<0.05$ ). While significant difference is seen in perceived stress scale on gender, physical education teaching (Stress Perception $\mathrm{U}=934.000, \mathrm{p}<0.05$ ) and classroom teaching (Insufficient Self-Efficacy Perception $\mathrm{U}=489.500, \mathrm{p}<0.05$ and), significant difference was identified in coping with stress scale in physical education (Submitting Approach $\mathrm{U}=1239.000, \mathrm{p}<0.05$ ) and pre-school teaching (Optimistic Approach $\mathrm{U}=223.000, \mathrm{p}<0.05)$.

Table 7. Result of Coping with Stress Scale on Exercising Kruskal Wallis Test

\begin{tabular}{cccccccc}
\hline $\begin{array}{c}\text { Coping with } \\
\text { Stress }\end{array}$ & Departments & $\begin{array}{l}\text { Exercising } \\
\text { Frequency }\end{array}$ & $\mathbf{n}$ & Order Avg. & Sd. & $\boldsymbol{X}^{\mathbf{2}}$ & $\mathbf{p}$ \\
\hline \multirow{2}{*}{$\begin{array}{c}\text { Optimistic } \\
\text { Approach }\end{array}$} & \multirow{2}{*}{ CRT } & Sometimes & 49 & 14 & 76.71 & & \\
& & No & 53 & 51.18 & 2 & 7.03 & 0.03 \\
Unconfident & \multirow{2}{*}{ PST } & Yes & 18 & 56.97 & & & \\
approach & & Sometimes & 58 & 47.30 & 2 & 6.68 & 0.04 \\
& & No & 31 & 64.81 & & & \\
\hline
\end{tabular}

According to Table 7; while a significant difference was observed in Optimistic Approach subdimension in classroom teaching students and Unconfident Approach sub-dimension in pre-school teaching students in coping with stress scale on exercising $(\mathrm{p}<0.05)$, no significant difference was observed in other sub-dimensions and departments ( $p>0.05$ ). The results of Mann-Whitney U test, which was performed to determine between which groups the difference is, are given below;

Table 8. Result of Coping with Stress Scale on Exercising U-Test

\begin{tabular}{cccccccc}
\hline $\begin{array}{c}\text { Coping with } \\
\text { Stress }\end{array}$ & Departments & $\begin{array}{c}\text { Exercising } \\
\text { Frequency }\end{array}$ & $\mathbf{n}$ & Order avg. & $\begin{array}{c}\text { Order } \\
\text { differences }\end{array}$ & $\mathbf{U}$ & $\mathbf{p}$ \\
\hline Optimistic & \multirow{2}{*}{ CRT } & Yes & 14 & 45.79 & 641.00 & 206,00 & 0,01 \\
Approach & & No & 53 & 30.89 & 1637.00 & & \\
Unconfident & \multirow{2}{*}{ PST } & Sometimes & 58 & 39.78 & 2307.50 & 596,50 & 0,01 \\
Approach & & No & 31 & 54.76 & 1697.50 & & \\
\hline
\end{tabular}

Table 9. Results of Cross-Scale Correlation Analysis

\begin{tabular}{|c|c|c|c|c|c|c|c|}
\hline \multirow[b]{2}{*}{$\begin{array}{c}\text { Scales } \\
\text { Playfulness }\end{array}$} & \multicolumn{5}{|c|}{ Coping with Stress } & \multicolumn{2}{|c|}{ Stress Perception } \\
\hline & 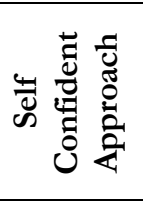 & 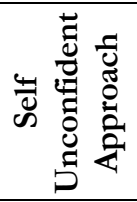 & 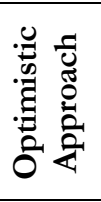 & 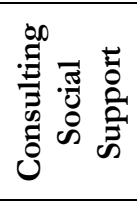 & 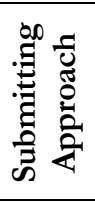 & 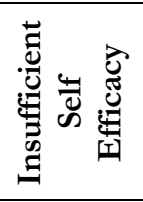 & के \\
\hline $\begin{array}{c}\text { Passion for } \\
\text { Games }\end{array}$ & -.03 & $.13^{*}$ & .09 & $-.14^{*}$ & $.23^{* *}$ & .08 & $-.12 *$ \\
\hline Risk Taking & $.21 *$ & -.01 & .16 & $-.12^{*}$ & $.12 *$ & -.10 & .01 \\
\hline Adaptation & $.26^{* *}$ & $-.11 *$ & $.21^{* *}$ & .05 & -.05 & $-.28^{* *}$ & .06 \\
\hline Desire to Play & $.22 * *$ & -.06 & $.27 * *$ & .03 & -.01 & $-.23 * *$ & .04 \\
\hline Enjoyment & $.16^{* *}$ & .08 & $.21 * *$ & $-.14 *$ & $.12 *$ & -.10 & .03 \\
\hline
\end{tabular}


Güvendi, B., \& Hazar, M. (2016). Playfulness, perceived stress and coping with stress approaches in teacher candidates in various departments. Journal of Human Sciences, 13(3), 5796-5806. doi:10.14687/ihs.v13i3.4348

When the correlation analyses of playfulness sub-dimensions and coping with stress subdimensions are examined; significance level relationship was found in Passion for Games and Unconfident approach $(\mathrm{r}=.13, \mathrm{P}<0.05)$, Consulting social support $(\mathrm{r}=.14, \mathrm{P}<0.05)$, Submitting approach $(\mathrm{r}=.23, \mathrm{P}<0.01)$, Risk taking and Self-confident approach $(\mathrm{r}=.21, \mathrm{P}<0.05)$, Consulting social support $(\mathrm{r}=-.12, \mathrm{P}<0.05)$, Submitting approach $(\mathrm{r}=.12, \mathrm{P}<0.05)$, Social adaptation and Selfconfident approach $(\mathrm{r}=.26, \mathrm{P}<0.01)$, Unconfident approach $(\mathrm{r}=.11, \mathrm{P}<0.05)$, Optimistic approach $(\mathrm{r}=.21, \mathrm{P}<0.01)$, Desire to play and Self-confident approach $(\mathrm{r}=.22, \mathrm{P}<0.01)$, Optimistic approach $(\mathrm{r}=.27, \mathrm{P}<0.01)$, Enjoyment and Self-confident approach $(\mathrm{r}=.16, \mathrm{P}<0.01)$, Optimistic approach $(\mathrm{r}=.21, \mathrm{P}<0.01)$, Consulting social support $(\mathrm{r}=-.14, \mathrm{P}<0.05)$, Submitting approach $(\mathrm{r}=.12, \mathrm{P}<0.05)$. Significant relationship was found between Passion for games and Stress perception $(\mathrm{r}=-.12$, $\mathrm{P}<0.05)$, Social adaptation and Insufficient self-management $(\mathrm{r}=-.25, \mathrm{P}<0.01)$, Desire to play and Insufficient self-management $(\mathrm{r}=-.23, \mathrm{P}<0.01)$ sub-dimensions of playfulness.

\section{Discussion}

According to the findings of the study to examine the playfulness, perceived stress and coping with stress styles in teacher candidates according to some independent variables and identify the relationships between;

When the average values of the scales are looked at; playfulness levels of physical education teachers are higher than classroom and pre-school teaching and perceived stress levels are lower than classroom and pre-school teaching. When the averages of coping with stress are looked at, coping with stress scores of physical education and classroom teaching students are identified to be higher than pre-school teaching. Accordingly, students studying at pre-school teaching are more shy compared to other departments. In the study conducted by Savci and Aysan (2014), the result was most of the students had middle level stress. In the study of Turkay and Sökmen (2014); score averages of coping with stress scale sub-dimensions and total of physical education and sports school students are seen to be higher than middle level. Akbağ et al. (2005); report that university students are mostly externally supervised, influenced more from physical stress resources and have high levels of depression symptoms. At the same time, the result of the way of supervision focus and self-interpretation, in other words, internal stress resources predict depression in a significant level was reached.

According to the results of playfulness scale on departments, physical education teaching students and pre-school teaching students are seen to have more playful characteristics. It may be thought that this is caused by most of the physical education students being engaged in sports since childhood.

According to the results of coping with stress scale, Consulting Social Support Approach scores of classroom teaching students are seen to be higher than physical education students, while physical education students' Optimistic Approach scores are seen to be higher than pre-school teaching students. In the study conducted by Savci and Aysan (2014), coping with stress styles of students by departments vary from each other.

No significant difference was seen in the sub-dimensions of perceived stress scale on department. In parallel to our study, Eraslan and Dunn (2015) in their study have reported that the perceived stress levels of university students studying in Physical Education and Sports School by age group and gender do not show statistically significant difference. Durna (2006) in his study has reported that there is a significant relationship between the stress levels by the type of school they are studying at.

In the playfulness scale on gender, enjoyment and passion for games values of males in physical education and pre-school teaching were seen to be higher, desire to play, social adaptation and enjoyment in classroom teaching students were found higher in female students than male students.

In the perceived stress scale on gender, while stress perception of females are more than males in physical education teaching, insufficient self-efficacy perception in classroom teaching was 
Güvendi, B., \& Hazar, M. (2016). Playfulness, perceived stress and coping with stress approaches in teacher candidates in various departments. Journal of Human Sciences, 13(3), 5796-5806. doi:10.14687/ihs.v13i3.4348

determined to be more than females. In the study conducted by Savci and Aysan (2014), perceived stress level of female students is found to be higher than male students. Batigun and Kayış (2014) found that females got higher scores than males in many stress causing factor dimensions and also is one of the predicting variables in gender regression equation. In another study, a significant relation between gender and student problems was identified and problems faced by females are more than those of males (Saracoğlu 1993). Different from the result of our study, Ustun and Bayar (2015) have found out in the study they made that between self-confidence and mother-father attitude factors in university students and depression, anxiety and stress levels a significant relation, while no relationship is present between gender factor and depression, anxiety and stress levels. Deniz and Sümer (2010) in the study they made, they reached a result that self-confidence in university students and depression, anxiety and stress level scores of individuals have a significant relationship. Durna (2006) in his study, couldn't find a significance between the genders and stress levels of students.

In the coping with stress level scale on gender, while submitting approach of males of physical education teaching students were seen as used more than females, males of pre-school teaching were seen to be using optimistic approach more than females. In the study conducted by Savci and Aysan (2014) female students were identified to be using planned problem solving and accepting responsibility strategies from the coping with stress strategies more than males. Different from our study, Turkay and Sokmen (2014) have reached the result of sub-dimension and total score averages of coping with stress scale by gender of candidates are not significantly different.

In the coping with stress scale on exercising; a significant difference was seen in Optimistic Approach sub-dimension of classroom teaching students, between those who exercise and those who don't. Accordingly, it was determined that those who exercise use optimistic approach more. As for the pre-school teaching students, a significant difference was identified between those who exercise sometimes and those who don't. Accordingly; it was seen that those who don't exercise used unconfident approach more than those who exercise, even sometimes. Then we can say that exercising has an active role in coping with stress.

According to correlation analysis; a significant relationship with negative direction between self-confident approach and stress perception and insufficient self-efficacy perception of the coping with stress scale sub-dimensions. Also, a significant relationship in positive direction was identified with unconfident approach and stress perception and insufficient self-efficacy. Accordingly, it can be said that as the levels of perceived stress of students increase they use unconfident approach more and self-confident approaches less. A significant relationship in negative direction was seen between optimistic approach and stress perception and insufficient self-efficacy perception. Accordingly, as the stress perception of the student's increase, their use of optimistic approach decreases. It can be thought that students use passive style more in the face of stress. A significant relationship in negative direction between consulting social support and insufficient self-efficacy was identified and a positive direction one between submitting approach and insufficient selfefficacy. As the stress perceptions of student's increase, their consulting social support approach decrease while using submitting approach increases. It can be said that students accept the problem and retreat instead of getting support in the face of stress. According to literature, playfulness is associated with many psychological events such as physiological benefits, physical activities, problem solving, emotional regulation, imagination, including different thoughts (Barnett, 1985, 1991; Barnett and Kleiber 1982; Brockman, Jago, and Fox, 2011; Christiano and Russ, 1996; Elias and Berk, 2002; Lieberman, 1965, 1977; Singer, Singer, and Sherrod, 1980; Vandenberg, 1980). Similarly, as a result of research made on coping with stress, it was noticed that playfulness is important in the process of coping with stress (Iwasaki, 2003; Pearlin, Mullan, Semple \& Skaff, 1990).

While a positive direction significant relationship is seen between passion for games from the playfulness scale sub-dimensions and submitting approach and unconfident approach, a negative direction significant relationship between passion for games and stress perception and consulting 
Güvendi, B., \& Hazar, M. (2016). Playfulness, perceived stress and coping with stress approaches in teacher candidates in various departments. Journal of Human Sciences, 13(3), 5796-5806. doi:10.14687/jhs.v13i3.4348

social support approach. It can be said that as the passion for games increase in students, they used submitting approach and unconfident approach more, stress perception decrease and consulting social support approach is used less. Increasing of passion for games causes the students to ignore the negative events and this in turn causes them not to need help, also even if they face such situation, they prefer passive fighting against stress more. While a positive direction significant relationship is observed between both risk taking and enjoyment and optimistic approach and submitting approach sub-dimensions of playfulness, a negative direction significant relationship was found between risk taking and consulting social support. As the risk taking and enjoyment levels of student's increase, it can be said that they use active coping more and don't need social support much in coping with stress. While a negative direction significant relationship is observed between social adaptation and insufficient self-efficacy perception and unconfident approach, a positive direction significant relationship between social adaptation and self-confident approach and optimistic approach. According to the study of Staempfli (2007) (coping with stress by playfulness in adolescents) playful teens are subjected to less stress. It was found that psychological stress is inversely proportional with playfulness. The more playful are the university students, they look for more social freedom to cope with stress. As the social adaptation levels of student's increase, their stress perceptions decrease and while using unconfident approach less, they used optimistic approach and self-confident approach more. Chan et al. (2013) have reported that as the playfulness increase, positive emotions and life satisfaction increases, also the increase of playfulness is related to decrease of negative emotions that affect stress. While a negative direction significant relationship is observed between desire to play and insufficient self-efficacy, a positive direction between self-confident approach and optimistic approach. Accordingly, as the desire to play increases in students, stress perception decrease and they used self-confident approach and optimistic approach more. Magnuson and Barnett (2013) have reported in the study they conducted that university students in low level playfulness group perceive more stress compared to middle and high level playfulness groups. Also, it was concluded that more playful individuals are stressed in lower level and playful individuals use similar coping methods in many situations. They stated that methods and frequency of use differ by playfulness levels and playful individuals may show considerable differences in perception and experiencing stress.

\section{Conclusions}

In conclusion, it was seen that playfulness characteristics are related with perceived stress and coping with stress methods, also physical education teaching students was more playful. However, it was also found that sub-dimensions of playfulness were effective and playfulness was used to cope with stress. It is thought that this study will contribute to the field in terms of working on a newly recognized subject such as playfulness, also the idea of playfulness being effective in coping with stress may be an example to new studies. The effect of playfulness on different subjects may be researched in the studies to be made.

\section{References}

Akbağ, M., Sayiner, B., \& Sozen, D. (2005). Stress level in university students an examination on the relationship between supervision focus and depression level. M.Ü. Atatürk Faculty of Education Journal of Education Sciences, 21: 59-74.

Aytaç, S. (2009). Work Stress Management Handbook, Work Stress: Creation, Reasons, Ways of Coping. Management. Labour Ministry- Casgem, pp.25-27.

Barnett, L. A. (1985). Young children's free play and problem-solving ability. Leisure Sciences, $7(1): 25-46$.

Barnett, L. A. (1990). "Playfulness: Definition. Design. and Measurement." In Theory in Context and Out. Play \& Culture Studies. Vol. 3. edited by Stuart Reifel, pp.319-36. 
Güvendi, B., \& Hazar, M. (2016). Playfulness, perceived stress and coping with stress approaches in teacher candidates in various departments. Journal of Human Sciences, 13(3), 5796-5806. doi:10.14687/jhs.v13i3.4348

Barnett, L. A. (1991). Characterizing playfulness: Correlates with individual attributes and personality traits. Play \& Culture, 4(4):371-393.

Barnett, L. A. (2007). “The Nature of Playfulness in Young Adults.” Personality and Individual Differences, 43:949-58.

Barnett, L. A. (2011-2012). "Playful People: Fun is in the Mind of the Beholder." Imagination. Cognition and Personality, 31:169-97.

Barnett, L. A., \& Kleiber, D. A. (1982). Concomitants of playfulness in early childhood: Cognitive abilities and gender. Journal of Genetic Psychology, pp.141-115.

Batigun, A. D., \& Kayış, A. A. (2014). Stress factors in university students: an evaluation in terms of interpersonal relationship styles and problem solving skills. Hacettepe University Journal of Faculty of Education, 29(2):69-80.

Bozionelos, N., \& Bozionelos, G. (1999). Playfulness: Its relationship with instrumental and expressive traits. Personality and Individual Differences, 26(4):749-760.

Brockman, R., Jago, R., \& Fox, K. R. (2011). Children's active play: Self-reported motivators, barriers and facilitators. BMC Public Health, 11(Suppl 4):461-467.

Chang, Po-Ju., Qian, X., \&Yarnal, C. (2013). Using playfulness to cope with psychological stress: taking into account both positive and negative emotions. International Journal of Play, 2(3):273-296.

Christiano, B., \& Russ, S. W. (1996). Play as a predictor of coping and distress in children during invasive dental procedure. Journal of Clinical Child Psychology, 25(2):130.

Cohen, S., Kamarck, T., \& Mermelstein, R. (1983). A global measure of perceived stress. Journal of Health and Social Behavior; 24:385-396

Deniz, M. E., \& Sümer, A. S. (2010). Evaluation of depression, anxiety and stress in university students with different self-understanding levels. Education and Science, 35(158):115-127.

Durna, U. (2006). Examination of stress levels of university students in terms of certain variables. Journal of Economic and Administrative Sciences, 20(1):319-343.

Elias, C. L., \& Berk, L. E. (2002). Self-regulation in young children: Is there a role for sociodramatic play? Early Childhood Research Quarterly, 17(2):216

Eraslan, M., \& Dunn, B. L. (2015). Examination of stress levels of physical education and sports school students in terms of certain variables. Niğde University Journal Of Physical Education And Sport Sciences, 9(1):179-185.

Eskin, M., Harlak, H., Demirkiran, F., \& Dereboy, Ç. (2013). Alg1lanan Stres Ölçeğinin Türkçeye Uyarlanması: Güvenirlik ve Geçerlik Analizi. New/Yeni Symposium Journal 51(3):132-140.

Folkman, S., \& Lazarus, R. S. (1980). An analysis of coping in a middle-aged community sample. Journal and Health Soc Behav; 21:219-39.

Glynn, M. A, \& Webster, J. (1992). The Adult Playfulness Scale: An Initial Assessme. Psychological Reports, 71:83-103.

Hazar, M. (2015). Attitudes of 18-22 aged adults towards playing games including physical activities (Development of Age 18-22 Playfulness Scale). Niğde University Journal of Physical Education and Sports School Sciences, 9(1):149-163.

Hellriegel, D., Slocum, J. W., \& Woodman, R. W. (1992). Organizational Behavior. St.Paul:West.

Iwasaki, Y. (2003). Examining rival models of leisure coping mechanisms. Leisure Science, 25(2):183-206.

Lazarus, R. S. (1966). Psychological Stress And The Coping Process. Mc Graw-Hill Company: New York.

Lazarus, R. S. (1999). Stress And Emotion: A New Synthesis. New York: Springer Publishing Company.

Lieberman, J. N. (1965). Playfulness and divergent thinking: An investigation of their relationship at the kindergarten level. Journal of Genetic Psychology, 107:219-224.

Lieberman, J. N. (1977). Playfulness: Its relationship to imagination and creativity. New York, NY: Academic Press. 
Güvendi, B., \& Hazar, M. (2016). Playfulness, perceived stress and coping with stress approaches in teacher candidates in various departments. Journal of Human Sciences, 13(3), 5796-5806. doi:10.14687/jhs.v13i3.4348

Magnuson, C. D., \& Barnett, L. A. (2013). The Playful Advantage: How Playfulness Enhances Coping with Stress. Leisure Sciences: An Interdisciplinary Journal, 35(2):129-144.

Pearlin, L., Mullan, J. T., Semple, S. J., \& Skaff, M.M. (1990). Caregiving and the stress process: An overview of concepts and their measures. The Gerontologist, 30(5):583-594.

Sahin, N., \& Durak, A. (1995). Coping with stress styles scale: adaptation for university students. Turkish Psychology Journal, 10(34):56-73.

Saracoğlu, S.. (1993). Certain Problems of Ondokuz Mayıs University Faculty of Education Students. Ondokuz Mayıs University Social Studies Institute. Postgraduate Thesis. Samsun.

Savc1, M., \& Aysan, F. (2014). Relationship between the perceived stress level and coping with stress strategies in university students. Journal of International Turkish Education Sciences, pp:44-56

Schaefer, C. E. (1993). "What is Play and Why Is It Therapeutic?" In The Therapeutic Powers of Play. Edited by Charles E. Schaefer, pp:1-15.

Singer, D., \& Singer, J. L. (1990). The house of make-believe: Play and the developing imagination. Cambridge. MA: Harvard University Press.

Singer, J. L., Singer, D. G., \& Sherrod, L. R. (1980). A factor analytic study of preschooler's play behavior. American Psychology Bulletin, 2:143-156.

Staempfli, M. B. (2007). Adolescent playfulness. stress perception. coping and well being. Journal of Leisure Research, 39(3):393-412.

Tertemiz, N. I. (2000). Problem Çözme. Ankara: Gündüz Eğitim ve Yayıncllık.

Trevlas, E., Grammatikopoulos, V., Tsigilis, N., \& Zachopoulou, E. (2003). Evaluating Playfulness: Construct Validity of the Children's Playfulness Scale. Early Childhood Education Journal, 31:33-9.

Tukenmez, M. (2009). Toplumbilim ve Spor. Istanbul: Kaynak Yayınları.

Turkay, H., \& Sökmen, T. (2014). Motivation resources and coping with stress styles of physical education and sports students in sports. İnönü University, Journal of Physical Education and Sports Sciences, 1(3):1-9.

Ustun, A., \& Bayar, A. (2015). Examination of depression, anxiety and stress levels of university students in terms of certain variables. Journal of Education and Research, $\quad 4(1): 384-390$.

Vandenberg, B. (1980). Play, problem-solving, and creativity. New Directions for Child Development, 9:49-68.

Vygotsky, L. R. (1978). Mind in society: The development of higher psychological processes. Cambridge, M. A: Harvard University Press. 